\title{
Betel Quid: Mood Elevator or Silent Killer?
}

\author{
Aniket Adhikari* \\ Department of Genetics, Vivekananda Institute of Medical Sciences, India
}

Submission: April 18, 2018; Published: May 09, 2018

*Corresponding author: Aniket Adhikari, Department of Genetics, Vivekananda Institute of Medical Sciences, Ramakrishna Mission Seva Pratishthan, Kolkata, India, Email: aniket_adhikari@rediffmail.com

\begin{abstract}
Betel chewing is a popular habit in Asia. Oral squamous cell Carcinoma or Oral cancer is one of the most common malignancies in South and South East Asian countries with betel quid chewing habit. Nitrosamines formed from alkaloids in betel nut during betel quid chewing may be implicated in the etiology of oral cancer. Reactive Oxygen Species (ROS) are generated due to slaked lime which is also present in betel quid. Mitotic activity has proven to be an efficient prognostic indicator of squamous cell carcinoma of various sites. Micronuclei (MN) have been proposed as a good biomarker to assess cytogenetic damage. The present review focuses on the adverse effects of betel quid with different abnormalities which acts as a mood elevator on Indian population.
\end{abstract}

Keywords: Betel quid; Toxicity; Oral Cancer; Micronuclei; Mitotic Index.

\section{Introduction}

The Mood Elevator: Take Charge of Your Feelings, Become a Better You. Human beings means we, all ride the mood elevator. We want to get relief from huge work pressure or changing our mood by using few mood elevators. We start our day in a great place and high mood after a morning run and a good breakfast.

Betel quid (BQ) is one of the mood elevating food in the world. An estimated 600 million people worldwide, $10 \%$ of the world's population, chew betel quid [1]. Betel quid chewing has been common in South and Southeast Asia, Asia Pacific Region for a long time [2]. Betel Quid (BQ) chewing, a habit practiced in India and other Asian countries, has known to be associated with cancer of the oral cavity. India has largest betel quid consuming population in the world.The habit of chewing betel quid is due to low cost, easily available and also as a mood elevator in the day to day busy scheduled life.

There are several types of chewing habits in India featuring use of betel quid (fresh betel leaf, fresh areca nut, slaked lime, catechu and tobacco), pan masala (areca nut, slaked lime, catechu, condiments and tobacco), mawa (areca nut, tobacco and slaked lime). BQ products have been classified by the International Agency for Research on Cancer (IARC) as group I human carcinogens.

The major areca nut alkaloids are arecoline, arecaidine, arecolidine, guvacoline and guacine [3]. Arecoline (1, 2, 4, 5,-tetrahydro-1-methylpyridinecarboxylic acid; molecular weight 155.19) is the most abundant alkaloid of areca. These alkaloids undergo nitrosation and give rise to $\mathrm{N}$-nitrosamines
[4], which may produce a variety of Betel Quid-Specific Nitrosoamines (BQSN). The BQSN interact with DNA, proteins or other target forming adducts to exert its carcinogenic activity. Slaked lime is also included in betel quid. It causes inflammation in the submucosal area.

It was reported that the $\mathrm{Ca}(\mathrm{OH}) 2$ of slaked lime in the presence of the areca nut is responsible for the formation of reactive oxygen species which cause oxidative damage in the DNA of buccal mucosa cells those who chew the betel quid [5].

In addition to these ingredients of betel quid, tooth attrition caused by the chewing action is also important for the establishment and development of oral cancers.

Micronuclei (MN) have been proposed as good biomarker to assess cytogenetic damage. MN formation has been observed in cancer and pre-cancerous lesions of the oral cavity of betel quid chewers. Statistically increased MN frequencies are observed in the buccal cells of various stages of oral cancer cases either may be in Pre Cancerous lesion or Pre cancerous condition. MN, which acts as a cancer biomarker, highly increase than normal in cancer cases and pre cancerous cases who had betel quid chewing habit [6].

M. Sulkowska [7], observed that mitotic index count was high in oral squamous cell carcinoma cases [7]. Mitotic Index (MI) activity has proven to be an efficient prognostic indicator of squamous cell carcinoma of various sites. Mitotic index are higher in cancer and pre cancer (both betel quid and non betel quid chewers) cases than normal. It was found that percentage 
of chromosomal aberration (CA) is higher in cancer cases with betel quid chewing habit. There is no Chromosomal Aberration (CA) was seen among healthy control. Chromosomal Aberration (aneuploidy) is found in betel quid chewers than normal. Statistically highly significant between betel quid, MN and MI $\left(\mathrm{p}<0.0001^{*}\right)[8]$.

\section{Conclusion}

Betel quid chewing is an ancient custom in several parts of south-east Asia and India. In our study we have screened 311 subjects from different areas of Eastern and North Eastern India and also from RKMSP hospital, Kolkata, India. Out of which $61.09 \%$ had betel quid chewing habit. Betel quid acts a mood elevator at one side for relaxation on human life and acts as a silent killer at another side by increasing percentage of MN (oral cancer biomarker) with Chromosomal Aberration (aneuploidy) which is related with oral cancer.

\section{References}

1. IARC (2009) Monographs Program; A review of human carcinogensPart E: tobacco, areca nut, alcohol, coal smoke, and salted fish Lancet Oncol 10(11): 1033-1034.
2. Gupta PC, Ray CS (2004) Epidemiology of betel quid usage. Ann Acad Med Singapore 33(4 Suppl): 31-36.

3. IARC (1985) Tobacco habits other than smoking; betel quid and arecanut chewing and some related nitrosamines. IARC Monograph on the Evaluation of Carcinogenic Risk of Chemicals to Humans, No 85. Lyon: International Agency for Research on Cancer.

4. Hoffmann D, Brunnemann KD, Prokopczyk B, Djordjevic MV (1994) Tobacco-specific N-nitrosamines and Areca-derived N-nitrosamines: chemistry, biochemistry, carcinogenicity, and relevance to humans. J Toxicol Env Health 41(1): 1-52.

5. Nair UJ, Friesen M, Richard I, MacLennan R, Thomas S, et al. (1990) Effect of lime composition on the formation of reactive oxygen species from areca nut extract in vitro. Carcinogenesis 11(12): 2145-2148.

6. Aniket Adhikari, Madhusnata De (2016) Micronuclei (Oral Cancer Biomarker) Study in Buccal Mucosal Cell with Betel Quid Chewers among Indian Population. ARC Journal of Cancer Science 2(1): 36-39.

7. Mariola Sulkowska, Waldemar Famulski, Stanislaw Sulkowski, Joanna Reszed, Maruisz Koda, et al. (2003) Correlation between Bcl -2 protein expression and some clinico pathological features of oral squamous cell carcinoma. Pol J Pathol 54(1): 49-52.

8. Aniket Adhikari, Madhusnata De (2017) Chromosomal Study among Betel Quid Chewers of Indian Population. Int J Recent Sci Res 8(6): 17625-17627.

\section{Your next submission with Juniper Publishers will reach you the below assets}

- Quality Editorial service

- Swift Peer Review

- Reprints availability

- E-prints Service

- Manuscript Podcast for convenient understanding

- Global attainment for your research

- Manuscript accessibility in different formats

( Pdf, E-pub, Full Text, Audio)

- Unceasing customer service

Track the below URL for one-step submission

https://juniperpublishers.com/online-submission.php 